\title{
Persepsi Pasien Terhadap Perilaku Caring Perawat di Ruang Rawat Inap Rumah Sakit
}

\section{Perception of Nurses' Caring Behavior in Inpatient Hospital}

\author{
Suryani Manurung* Mey Lys Ceryah Hutasoit**
}

*Jurusan Keperawatan Politeknik Kesehatan Jakarta I, **Rumah Sakit Ichsan Madical Centre Bintaro

\begin{abstract}
Abstrak
Rumah sakit berupaya menciptakan mutu pelayanan yang terbaik sebagai salah satu faktor penentu citra di masyarakat. Perilaku caring perawat merupakan salah satu indikator mutu pelayanan yang diterima oleh masyarakat. Tujuan penelitian ini untuk mengetahui faktor-faktor yang memengaruhi persepsi pasien terhadap perilaku caring perawat di Rumah Sakit Ichsan Medical Centre Bintaro dengan desain potong lintang. Populasi adalah pasien rawat inap dengan pengambilan sampel random sampling sebesar 93. Data dianalisis dengan univariat sampai bivariat dengan analisis kai kuadrat. Hasil penelitian menunjukkan faktor yang berhubungan dengan persepsi pasien yang menjalani perawatan di rawat inap Rumah Sakit Ichsan Medical Centre Bintaro adalah kebutuhan caring (nilai $p=0,001$ ) dan perilaku caring perawat (nilai $p=0,006$ ). Terpenuhinya kebutuhan caring dan perbaikan perilaku caring perawat akan menjadikan persepsi pasien menjadi positif selama rawat inap.
\end{abstract}

Kata kunci: Perawat, perilaku caring, persepsi pasien

\begin{abstract}
The hospital strives to create the best quality of service as a determining factor for the image in society. Nurse caring behavior is one indicator of the quality of service received by the public. The purpose of this study was to determine the factors that influence patient perception to nurse caring behaviors in Ichsan Medical Centre Hospital Bintaro with cross sectional design. The population was inpatients with sampling random sampling of 93 . Data were analyzed by univariate and bivariate by chi-square analysis. The results showed that associated factors with the perception of patients undergoing inpatient treatment at Ichsan Medical Centre Hospital Bintaro is caring needs ( $p$ value $=0.001)$ and the nurse caring behaviors $(p$ value $=$ 0.006). The fulfillment needs of caring and repair will make the nurse caring behaviors the perception become positive patients during hospitalization.

Keywords: Nurses, caring behavior, patient perception
\end{abstract}

\section{Pendahuluan}

Caring merupakan salah satu tindakan keperawatan yang dilakukan setiap hari secara terus menerus, tulus, ikhlas, peduli dengan masalah pasien yang dihadapi. ${ }^{1}$ Dalam memberikan pelayanan keperawatan, perlu diperhatikan tiga aspek yakni care, cure, dan core. Proporsi pelayanan yang diberikan sebanyak tiga per empatnya adalah caring (tindakan yang berfokus pada kenyamanan dan kepuasan bagi klien selama dirawat), sedangkan seperempatnya adalah curing (tindakan pengobatan yang diberikan dalam proses penyembuhan). ${ }^{2}$ Perilaku caring perawat merupakan hal yang penting bagi pasien sebagai pengguna jasa dalam pelayanan keperawatan yang akan membantu salah satu proses dari kesembuhan pasien itu sendiri.

Peran perawat saat ini lebih banyak terlibat aktif dan memusatkan diri pada tindakan cure seperti cara diagnostik dan pengobatan. Ilmu pengetahuan dan teknologi yang berkembang saat ini, menuntut melakukan peran ganda dalam menjalani tugas caring dan curing. Faktor lain yang memengaruhi perilaku caring perawat dalam memberikan pelayanan keperawatan adalah beban kerja perawat yang banyak. ${ }^{3}$

Rawat inap umum Rumah Sakit Ichsan Medical Centre (IMC) Bintaro memiliki 41 tempat tidur dengan jumlah tenaga perawat 9 orang perawat. Tenaga perawat tersebut dibagi menjadi tiga sif, yang terdiri dari dua sampai tiga orang perawat, satu orang penanggung jawab pasien, satu orang penanggung jawab pengobatan

Alamat Korespondensi: Suryani Manurung, Jurusan Keperawatan Poltekkes Kementerian Kesehatan Jakarta I, Jl. Wijayakusuma Raya No. 47-48 Cilandak Jakarta Selatan, Hp.081219969292,e-mail: yani_manru@yahoo.co.id 
dengan rata-rata maksimal pasien yang di rawat dalam satu hari 20 pasien.

Peraturan kementerian kesehatan Nomor 262/MenKes/Per/VII/1979 menetapkan bahwa perbandingan jumlah tempat tidur rumah sakit dibandingkan dengan jumlah perawat berbanding $3-4: 2$. Jumlah tenaga keperawatan dibandingkan dengan pasien adalah $5: 9$ untuk setiap sif. ${ }^{4,5}$ Bila jumlah tenaga perawat tidak sesuai dengan jumlah pasien mengakibatkan beban tugas perawat berlebih selama memberikan pelayanan keperawatan.

Beban kerja yang berlebihan berdampak terhadap fisik, psikologis dan sikap (perilaku) yang disebut dengan stres kerja. ${ }^{6}$ Pengaruh negatif yang ditimbulkan antara lain terhadap psikologis berupa gangguan emosional sampai dengan penurunan motivasi bekerja. Kondisi fisik mengalami gangguan fungsi organ tubuh, seperti pencernaan, pernapasan, dan kondisi perilaku, memiliki hubungan interaksi yang tidak baik seperti berbicara.

Berdasarkan kuesioner (kotak saran) bulan Januari Maret 2011 Rumah Sakit IMC Bintaro, ada beberapa penilaian pasien tentang pelayanan. Pasien menginginkan pelayanan keperawatan peduli terhadap keluhan dan kebutuhan pasien. Beberapa sikap dan perilaku tersebut terlihat di saat perawat memberikan pelayanan asuhan keperawatan sehingga memunculkan asumsi pasien tersebut bahwa pelayanan yang diberikan oleh perawat tidak bermutu. 3,6

Faktor yang membatasi partisipasi pasien selama perawatan adalah terbatasnya komunikasi antara perawat dan pasien, berorientasi tugas tenaga keperawatan, dan lingkungan yang membatasi jarak antara pasien dan petugas kesehatan. ${ }^{7}$ Berdasarkan pelayanan keperawatan yang dirasakan pasien di Rumah Sakit IMC Bintaro, hal ini menggambarkan masih kurangnya perilaku caring perawat yang dirasakan oleh masyarakat selama dirawat. Penelitian ini bertujuan untuk mengetahui faktor yang berhubungan dengan persepsi pasien terhadap perilaku caring perawat di Rumah Sakit IMC Bintaro.

\section{Metode}

Desain penelitian yang digunakan adalah potong lintang. Penelitian dilaksanakan pada bulan Juni Agustus 2011 di Rumah Sakit IMC Bintaro. Populasi penelitian adalah pasien yang dirawat di Rumah Sakit IMC Bintaro. Pengambilan sampel sesuai dengan kriteria inklusi, yaitu pasien dewasa yang dirawat diruang penyakit dalam dan tidak mengalami gangguan kejiwaan. Teknik pengambilan sampel adalah simple random sampling, yaitu dengan undian menggunakan tabel bilangan/angka acak (random number). Jumlah sampel dari perhitungan adalah 93 responden.

Instrumen penelitian adalah kuesioner yang dikembangkan oleh peneliti berdasarkan kerangka konsep, yaitu karakteristik responden, persepsi pasien, kebutuhan caring, penerimaan diri pasien, dan perilaku caring perawat. Kuesioner ini digunakan setelah dilakukan uji validitas dan reliabilitas. Pengumpulan data dilakukan setelah responden bersedia, memberikan penjelasan cara pengisian kuesioner, dan memberikan kesempatan pada pasien untuk mengisinya. Kuesioner dikumpulkan kembali dan dianalisis.

Data yang telah terkumpul dianalisis secara univariat menggunakan distribusi frekuensi dan bivariat menggunakan uji statistik kai kuadrat $\left(\mathrm{X}^{2}\right)$ dengan menggunakan program analisis statistik.

\section{Hasil}

Pada Tabel 1 terlihat bahwa sebagian besar responden yang dirawat di Rumah Sakit IMC Bintaro berjenis kelamin perempuan $(65,6 \%)$ dan memiliki tingkat pendidikan tinggi $(74,2 \%)$ serta tingkat sosial ekonomi yang tinggi $(51,6 \%)$. Tabel 2 menunjukkan bahwa pasien yang memiliki persepsi positif terhadap perilaku caring perawat sebanyak $61,3 \%$ dan pasien yang merasakan kebutuhan caring selama dirawat cukup tinggi, yaitu $55,9 \%$. Pasien yang dirawat sebagian besar dapat menerima kondisi dirinya dengan baik selama dirawat (71\%) serta menyatakan perilaku caring perawat selama memberikan pelayanan adalah baik $(75,2 \%)$ (Tabel 3$)$.

Karakteristik responden pada penelitian ini adalah jenis kelamin, pendidikan, dan status sosial ekonomi.

Tabel 1. Karakteristik Responden

\begin{tabular}{llll}
\hline Variabel & Kategori & n & $\%$ \\
\hline Jenis kelamin & Laki-laki & 32 & 34.4 \\
\multirow{2}{*}{ Tingkat pendidikan } & Perempuan & 61 & 65.6 \\
& Rendah & 24 & 25.8 \\
Sosial ekonomi & Tinggi & 69 & 74.2 \\
& Rendah & 45 & 48.4 \\
& Tinggi & 48 & 51.6 \\
\hline
\end{tabular}

Tabel 2. Gambaran Persepsi Pasien Rawat Inap dan Kebutuhan Caring

\begin{tabular}{llll}
\hline Variabel & Kategori & n & $\%$ \\
\hline Persepsi pasien & Negatif & 36 & 38.7 \\
& Positif & 57 & 61,3 \\
Kebutuhan caring & Rendah & 41 & 44,1 \\
& Tinggi & 52 & 55.9 \\
\hline
\end{tabular}

Tabel 3. Penerimaan Diri Pasien Selama Dirawat dan Perilaku Caring Perawat

\begin{tabular}{lllll}
\hline & \multicolumn{5}{c}{ Kategori } \\
\cline { 2 - 5 } Variabel & \multicolumn{2}{c}{ Kurang } & \multicolumn{2}{c}{ Baik } \\
\cline { 2 - 5 } & $\mathbf{n}$ & $\%$ & n & $\%$ \\
\hline Penerimaan diri & 27 & 29 & 66 & 71 \\
Perilaku caring perawat & 23 & 24,6 & 70 & 75,2 \\
\hline
\end{tabular}


Tabel 4. Hubungan Karakteristik Responden, Kebutuhan Caring, Penerimaan Diri, dan Perilaku Caring dengan Persepsi Pasien terhadap Perilaku Caring Perawat

\begin{tabular}{|c|c|c|c|c|c|c|c|c|}
\hline \multirow{3}{*}{ Variabel } & & \multicolumn{4}{|c|}{ Persepsi Pasien } & \multirow{3}{*}{ OR } & \multirow{3}{*}{$95 \% \mathrm{CI}$} & \multirow{3}{*}{ Nilai $p$} \\
\hline & & \multicolumn{2}{|c|}{ Negatif } & \multicolumn{2}{|c|}{ Positif } & & & \\
\hline & & $\mathbf{n}$ & $\%$ & $\mathbf{n}$ & $\%$ & & & \\
\hline \multirow[t]{2}{*}{ Jenis kelamin } & Laki-laki & 13 & 40,6 & 19 & 50,4 & 1,130 & $0.471-2.712$ & 0.960 \\
\hline & Perempuan & 23 & 37,7 & 38 & 62,3 & & & \\
\hline \multirow[t]{2}{*}{ Pendidikan } & Rendah & 12 & 50 & 12 & 50 & 1.875 & $0,732-4.805$ & 0.828 \\
\hline & Tinggi & 24 & 34,8 & 45 & 65,2 & & & \\
\hline \multirow{2}{*}{ Sosial ekonomi } & Rendah & 17 & 37,8 & 28 & 62.2 & 0,927 & $0.402-2.317$ & 1.000 \\
\hline & Tinggi & 19 & 36,6 & 29 & 60.4 & & & \\
\hline \multirow[t]{2}{*}{ Kebutuhan caring } & Kurang & 24 & 58,5 & 17 & 41,5 & 4,076 & $1.922-11.524$ & 0,001 \\
\hline & Baik & 12 & 23,1 & 40 & 76,9 & & & \\
\hline \multirow[t]{2}{*}{ Penerimaan diri } & Kurang & 14 & 51,9 & 13 & 48,1 & 2.154 & $0.865-5.362$ & 0.153 \\
\hline & Baik & 22 & 33,3 & 44 & 66,7 & & & \\
\hline \multirow[t]{2}{*}{ Perilaku caring } & Kurang & 15 & 65,2 & 8 & 34,8 & 4,376 & $1.611-11.878$ & 0,006 \\
\hline & Baik & 21 & 30 & 49 & 70 & & & \\
\hline
\end{tabular}

Hasil analisis menunjukkan tidak ada perbedaan yang bermakna antara responden yang memiliki persepsi negatif dan positif (nilai $\mathrm{p}>$ alpha $5 \%$ ). Pasien yang memiliki persepsi negatif dan positif terhadap kebutuhan caring menunjukkan perbedaan yang bermakna. Hasil uji statistik menunjukkan nilai $\mathrm{p}=0,001$, artinya pada $\alpha=$ $5 \%$ terdapat perbedaan yang signifikan antara responden yang mengatakan kebutuhan caring kurang dengan kebutuhan caring baik ( $\mathrm{OR}=4,076)$, artinya pasien yang mengatakan kebutuhan caring kurang lebih cenderung memiliki persepsi negatif sebesar 4,076 kali dibandingkan yang mengatakan persepsi caring baik.

Perilaku caring perawat berdasarkan persepsi pasien, terdapat perbedaan yang bermakna antara yang memiliki persepsi negatif dan positif. Hasil uji statistik menunjukkan nilai $\mathrm{p}=0,006$ artinya pada $\alpha=5 \%$ terdapat hubungan yang signifikan antara perilaku caring dengan persepsi pasien $(\mathrm{OR}=4,376)$, artinya pasien yang mengatakan perilaku caring kurang memiliki peluang/kecenderungan sebesar 4,376 kali untuk memiliki persepsi negatif terhadap perilaku caring perawat dibandingkan responden yang mengatakan perilaku caring perawat baik (Tabel 4).

\section{Pembahasan}

Persepsi atau tanggapan adalah proses mental yang terjadi pada diri manusia yang akan menunjukkan bagaimana kita melihat, mendengar, merasakan, memberi, serta meraba (kerja indra) di sekitar kita. ${ }^{8,9}$ Hasil penelitian menunjukkan bahwa faktor yang memengaruhi persepsi pasien terhadap perilaku caring perawat adalah kebutuhan caring responden dan perilaku caring.

Caring adalah dasar atau aspek dominan dalam praktik keperawatan sehari-hari. ${ }^{1,2}$ Namun fenomena yang ditemukan pada pelayanan keperawatan lebih banyak mengerjakan curing (pengobatan). Persepsi pasien ter- hadap kebutuhan caring dan perilaku caring perawat dipengaruhi oleh banyak faktor. Kemampuan kompetensi klinis yang dirasakan oleh pasien ketika mendapatkan pelayanan dari perawat. ${ }^{10,11}$ Kemampuan dan kompetensi seorang perawat dibekali dengan pengetahuan yang cukup dalam mengerjakan pelayanan keperawatan. Setiap pelayanan yang diberikan mencakup elemen keamanan dan kenyamanan pasien (fisik dan lingkungan), sistematika prosedur dan komunikasi terapeutik. Ketiga elemen ini jika dilakukan dengan benar memberikan persepsi pasien akan kebutuhan caring yang diterima dan perilaku caring menjadi lebih baik. Pada penelitian ini, variabel kompetensi perawat tidak diteliti namun peneliti sebelumnya menemukan ada hubungan prioritas kompetensi klinis perawat, yang dilakukan Rumah Sakit IMC Bintaro bagian emergensi tahun 2002.

Usia berhubungan dengan kebutuhan caring pasien dan perilaku caring. Hasil penelitian sebelumnya menunjukkan perbedaan usia yang signifikan untuk setiap pernyataan kebutuhan caring dan perilaku caring. Semakin tua usia pasien, semakin besar pentingnya perilaku caring perawat dan kebutuhan caring. ${ }^{11,12}$ Orang tua umumnya merasa rentan dan sangat sensitif terhadap bantuan yang diterimanya selama dirinya dirawat. Pada umumnya, orang-orang yang berada pada risiko yang lebih tinggi terkena penyakit penting untuk mengetahui bahwa penyedia layanan kesehatan adalah para profesional yang kompeten dan siap untuk merawat mereka.

Pada penelitian ini, jenis kelamin dan tingkat pendidikan tidak memiliki hubungan yang bermakna terhadap persepsi negatif terhadap perilaku caring. Namun, pada penelitian sebelumnya jenis kelamin dan pendidikan memiliki hubungan bermakna terhadap perilaku caring perawat. Peran gender (antara pria dan wanita) mengacu pada bagaimana seseorang berperilaku, biasanya wanita lebih sensitif daripada pria sehingga dalam 
mempersepsikan suatu keadaan biasanya wanita lebih peka, artinya bila suatu keadaan tersebut tidak sesuai dengan apa yang diharapkan maka wanita lebih cepat memberikan persepsi negatif dibandingkan dengan pria. Demikian pula responden dengan tingkat pendidikan yang tinggi dan rendah memiliki perbedaan dalam memberikan persepsi perilaku caring perawat. Pendidikan merupakan hal penting dalam mempersepsikan sesuatu hal yang dilihat dan dirasakan oleh seseorang.

Sosial ekonomi dengan persepsi pasien terhadap perilaku caring perawat. Pada penelitian ini tidak ditemukan hubungan sosial ekonomi dengan persepsi pasien. Dalam kehidupan sehari-hari, semakin tinggi nilai sosial dan ekonomi seseorang, semakin tinggi pula keinginan seseorang untuk mendapatkan suatu pelayanan. Pada umumnya, seorang pasien yang sudah terbiasa dengan cara hidup melakukan segala hal sendiri tentunya akan merasa tidak senang bila perawat berbuat sesuai dengan tugasnya (membasuhnya, menyuapinya, dan lain-lain). Adapun pasien yang pada masa ia sehat terbiasa hidup dengan pelayanan yang dipusatkan pada pemuasan semua keinginannya, akan menuntut perlakuan yang diperolehnya dalam hidupnya sehari-hari dipenuhi oleh perawat. Pada penelitian sebelumnya oleh Nikolaus, ${ }^{13}$ terdapat hubungan antara persepsi dengan sosial ekonomi. Hal tersebut terlihat berdasarkan adanya perbedaan pelayanan dengan struktur kelas ruang rawat pasien.

Beberapa hal yang dapat dikembangkan oleh perawat dalam merangsang persepsi pasien adalah memanusiakan pasien, terlibat langsung dengan pasien dalam memberikan pelayanan dalam bentuk informasi maupun tindakan, memiliki kompeten dalam melayani khusus pelayanan yang bersifat caring. ${ }^{10}$ Sebagaimana yang dinyatakan dalam karakteristik caring, yaitu mengutamakan nilai-nilai kemanusiaan, menanamkan kepercayaan, dan harapan pasien, mengembangkan kepekaan terhadap diri sendiri dan orang lain, mengembangkan bantuan, dan hubungan saling percaya, meningkatkan dan menerima ungkapan perasaan yang positif dan negatif, sistematis dalam metode pemecahan masalah, mengembangkan pendidikan dan pengetahuan internasional, meningkatkan dukungan, perlindungan mental, fisik, sosial budaya dan lingkungan spiritual, senang membantu kebutuhan pasien. ${ }^{1}$

\section{Kesimpulan}

Berdasarkan hasil penelitian yang telah dilakukan, dapat disimpulkan bahwa faktor yang yang berhubungan dengan persepsi pasien terhadap perilaku caring perawat di unit rawat inap umum di Rumah Sakit IMC Bintaro adalah kebutuhan caring dan perilaku caring perawat. Faktor lainnya, yakni karakteristik responden dan penerimaan diri tidak memiliki hubungan dengan persepsi pasien terhadap perilaku caring.

\section{Saran}

Adanya faktor yang ditemukan dalam memengaruhi persepsi pasien terhadap perilaku caring perawat, maka perlu upaya oleh institusi rumah sakit untuk memperbaiki kinerja perawat dalam hal memberikan pelayanan caring pada setiap pasien yang dilayani.

Upaya yang dapat dilakukan saat ini yaitu meningkatkan pengetahuan dan psikomotor perawat. Dengan meningkatnya kualitas kinerja perawat, pelayanan caring pada pasien juga dapat meningkat.

\section{Daftar Pustaka}

1. Watson Caring Science Institute and International Carita Consortium. Caring science (defenitions, process, theory) (Homepage internet). USA: Watson Caring Science Institute and International; 2011 [cited 2011 Jul 20]. Available from: Watsoncaringscience.org/about-us/.

2. Lydia EH. The aspects of care, core, cure [homepage internet]. Gonzalo: 2011 [cited 2011 Juli 2011]. Available from: http://nursing theories.weebly.com/

3. Motowidlo SJ, Manning MR, Packard JS. Stress: its causes and consequences for job performance. J App Psychology [serial on internet]. 1986 [cited 2011 Aug 2013]: 71 (4): 618-29. Available from: http://www.telemainternational.com

4. Direktorat Rumah Sakit Umum dan Pendidikan, Direktorat jenderal pelayanan Medik Departemen Kesehatan Republik Indonesia. Standar peralatan ruang dan tenaga rumah Sakit kelas C. Edisi ke-5. Jakarta: Departemen Kesehatan Republik Indonesia; 1998.

5. Direktorat Rumah Sakit Umum dan Pendidikan, Direktorat jenderal pelayanan Medik Departemen Kesehatan Republik Indonesia. Standar asuhan keperawatan. Edisi ke-5. Jakarta: Departemen Kesehatan Republik Indonesia; 1998.

6. Bharatiya Vidya Bhavan's Usha and Lakshmi Mittal Institute of Management, New Delhi, India. A Study on work stress, causes, symptoms and impact. Int J Innov Res Stu (serial on the internet). 2013 [cited 2013 Okt 2013]: 2 (5). Available from: www.ijirs.com./vol2_issue5/20.pdf.

7. Lillibridge WJ, Beanland C, Lewis M. Consumer participation in acute care settings: an Australian experience . Int J Nurs Prac [serial on internet]. 2003 Aug [cited 2012 March 10]: 9 (4): 255-60. Available from: www.ncbi.nlm.nih.gov/pubmed/12887377.

8. Sobur A. Psikologi umum. Bandung: CV Pustaka Setia; 2009.

9. Cherry K. Perception and the perceptual process [online] [cited 2013 March 4]. Available from: http://psychology.about.com/od/sensationandperception/ss/perceptroc.htm.

10. Larsson IE, Sahlsten MJM, Segesten K, Plos KAE. Patients perceptions of nurses behaviour that influence patient participation in nursing care: a critical incident study. J Nurs Res Pract [serial on internet]. 2011 [cited 2012 Nov 8]; about 8 pages. Available from: http://www.hindawi. com/journals/nrp/2011/534060/.

11. Baldursdottir G, Jonsdottir H. The importance of nurse caring behaviors as perceived by patients receiving care at an emergency department. Journal Heart Lung. 2002 Jan-Feb [cited 2012 March 5]; 31(1): 67-75. Available from: www.ncbi.nlm.nih.gov/pubmed/11805752.

12. DeVoe JE,Wallace LS, Fryer GE Jr. Patient age influences perceptions- 
Kesmas, Jurnal Kesehatan Masyarakat Nasional Vol. 8, No. 3, Oktober 2013

about health care communication. J Fam Med [serial on internet]. 2009 cited 2012 Jul 15]: 41(2):126-33. Available from: www.ncbi.nlm. nih.gov/pubmed/19184691.

13. Nikolaus. Faktor-faktor yang mempengaruhi persepsi pasien terhadap perilaku caring perawat dalam praktek keperawatan di IRNA Medikal Bedah RSUD Kupang [online]. 2002 [diakses tanggal 30 Maret 2012]. Diunduh dalam: www.scribd.com/doc/155452800/Nikolaus-NKewauan-G. 